\title{
多荷重条件下の積層材の強度最適化
}

\author{
福 永久 雄* \\ (1990 年 3 月 14 日受付)
}

\section{Strength Optimization of Laminated Composites under Multiple Loading H. FuKunAGA*}

(Received March 14, 1990)

\begin{abstract}
The present paper deals with the strength optimization of laminated composites under multiple loading based upon a mathematical programming method. A method using the transformed design variables with respect to the layer angles is proposed. In order to reduce the nonlinearity between the strength constraints and the layer angles, $\cos 2 \theta$ or $\sin 2 \theta$ is used as the design variable instead of using $\theta$ directly. It is shown through several numerical examples that the present method gives reliable optimal results which are less sensitive to initial values used in the optimization.
\end{abstract}

\section{1. 序}

複令材情造は痛厚のみならず絨維角も設䛅できる設計

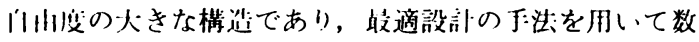
值的に棈造設訃を行うのにきわめて適した構造でもあ る. 最適設計の観点からは, 大きく, 強度最適化問題と

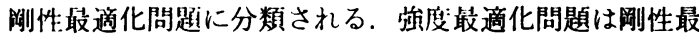
適化問题に比べ多数の制約条件を伴ら問題であり，従

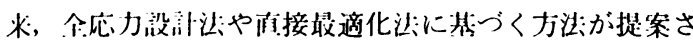
れているが1，さらに，效摔がよく安分した解法が要求 されている，本論文では，强度最適化問題で緎維角を効 凌的に最適化する丁泣について检剖する.

䅡層材の出度を聂大とする程層構成を求める研究は, これまで，多数行われてきたが，ほとんどの研究は子め

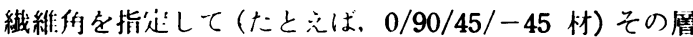
情を最適化するものである，層厚に加え瀻維角を最適化 する研究は少なく，繊維㑇が多い場合に適用可能な手法 はごく限られてい、る2-4)

面内荷重を受ける皘辡柲におい:て，層厚の最適化に比 べ㵶維角の最適化はかなり困難であるが，その理由は， 而内剛性特性は層厚の一次関数であるのに対し，瀻維角 については $\cos 2 \theta, \cos 4 \theta, \sin 2 \theta, \sin 4 \theta$ を合複雑な

\section{* 航空宇宙技術研究所機体部立任研究官 $(181$ 三鷹} 市大沢 6-13-1)

Senior Researcher, Airframe Div., National Aerospace Laboratory, 6-13-1, Osawa, Mitaka 181, Japan
闺数形をしていることにある。そのため，最適化におい て織維角を直接に設計変数に用いると，しばしぱ，局所 的な最適点で計算がストップし，初期値依有性の強い維 果しか得られないことになる。

単一の面内荷重を受ける積層板の場合は，前報2)にお いて，せん断荷重がゼロとなる主荷重方向のバランスト 皘層材について最適化する手法を提案した。 バランスト 材では, 面内剛性は層厚の一次関数，㵶維角については $x_{i}=\cos 2 \theta i$ を設計変数とすると $x_{i}$ の二次関数で表示さ れる. 注荷重力向の利用とバランスト材に対する変換し た設汁変数の使用により，剛性と絨維角の非線形性の程 度が非常に弱くなり，初期値にほとんど依存しない最適 皘層構成を求めることができた。しかし，主荷重力向を 利用できるのは単一荷車の場合に限定され，多荷車条件 では適州できない。

多荷重条件の場合の強度最適化の研究として, 層片と

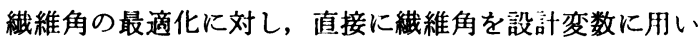
て，Park ${ }^{3)}$ はュンブレックス法を，Watkins ら4)は逐次 線形計画法を適用している。 また，Schmit ら5)は，層厚 を設計変数と寸る場合に，内接超球法を適用している。 層厚最適化の場合は, 層厚ゼロの層をうまく処理する必 要2）があるにしても，適当な最適化丁:沙を適用すること により，初期值依存性の少ない安定した最適解を得るこ とが闪能である。しかし，層厚に加总緎維角を最適化す る場令には，従米の研究におけるように，直接に緎維㑬 を設計变数に用いて最適化しても，初期俏低存性の少な い安定した最適解を得ることが難しい。 
本報では，剛性と緘維角の非線形性を减少させるた め, 变換した設汁变数を使川した多矿重条件下の強废取 適化の手法を提案する. 直接に緎維角を設計変数に用い るのではなく, $\cos 2 \theta$ か $\sin 2 \theta$ を設計变数として積層 材の強度最適化を行う，単一·あるいは複数の面内荷重を 受ける CFRP 積層材について，本手法の有効性を検討 するとともに, いくつかの荷重条件のもとで最適な積層 構成を調べる.

\section{2. 最適钤計問題の定式化}

Fig. 1 に示す面内荷重 $\left(N_{x}, N_{y}, N_{x y}\right)$ を受ける積層板 の強度制約条件下での最小重量設計問題を考える. 強度 基售として Tsai-Wu 則 $\left(F_{12} *=-1 / 2\right)$ を用い, 複数の 荷重条件が独立に働く多荷重条件下の問題とする．最適 化問題の定式化は, 単一荷重下での前報2)での定式化と ほとんど同じであり次のように表示できる.

[月似成数] $W=\sum_{i=1}^{I} h_{i}$ を熶小

[制約条件] $g_{j}=V_{k i}-1 \leqq 0 \quad(j=1,2, \cdots, K I)$

$$
h_{i} L \leqq h_{i} \leqq h_{i} U \quad(i=1,2, \cdots, I)
$$

[設淬十変数] $h_{i}, \theta i$

$(i=1,2, \cdots, I)$

ここで, $h_{i}, \theta i$ は $i$ 番目層の層厚および織維角であり, 層厚に関しては上下限值が指定されているものとする.

また, $V_{k i}$ は $k(k=1,2, \cdots, K)$ 番月の荷重条件に対応 する $i$ 番目層の破損条件であり，Tsai-Wu 則では次式 となる.

$$
\begin{aligned}
V_{k i}= & F_{1} \sigma_{L}+F_{2} \sigma_{T}+F_{11} \sigma_{L}{ }^{2}+2 F_{12} \sigma_{L} \sigma_{T} \\
& +F_{22} \sigma_{T} T^{2}+F_{66 \tau} \tau T^{2} \leqq 1
\end{aligned}
$$

ここで, $\left(\sigma_{L}, \sigma_{T}, \tau L T\right)$ は䄉維方向座標における応力成 分であり，制約条件数は層数と荷重条件数とを掛命わせ た $K I$ 偑である.

\section{3. 棫維角に関する变換した設計变数}

古典皘層理論では, 而内の令力-震み関係は次式で示

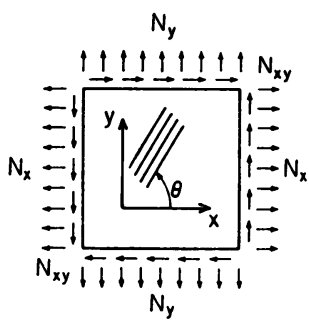

Fig. 1 Symmetric laminate under in-plane loading.
$さ れ て,$.

$$
\left\{\begin{array}{l}
N_{x} \\
N_{y} \\
N_{x y}
\end{array}\right\}_{k}=\left[\begin{array}{lll}
A_{11} & A_{12} & A_{16} \\
A_{12} & A_{22} & A_{26} \\
A_{16} & A_{26} & A_{66}
\end{array}\right]\left\{\begin{array}{l}
\varepsilon_{x} \\
\varepsilon_{y} \\
\gamma_{x y}
\end{array}\right\}_{k}
$$

ここで, $\left(N_{x}, N_{y}, N_{x y}\right)_{k}$ および $\left(\varepsilon_{x}, \varepsilon_{y}, \gamma_{x y}\right)_{k}$ は, $k$ 米 目 $(k=1,2, \cdots, K)$ の街重条件および対応する企みであ る. 雪みが求まれば各種の応力が求まり，（2）式により

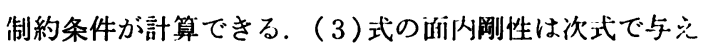
られる。

$$
\begin{aligned}
& A_{11}=\sum_{i=1}^{I} h_{i}\left[U_{1}+U_{2} \cos 2 \theta i+U_{3} \cos 4 \theta i\right] \\
& A_{22}=\sum_{i=1}^{I} h_{i}\left[U_{1}-U_{2} \cos 2 \theta_{i}+U_{3} \cos 4 \theta i\right] \\
& A_{12}=\sum_{i=1}^{I} h_{i}\left[U_{4}-U_{3} \cos 4 \theta i\right] \\
& A_{66}=\sum_{i=1}^{I} h_{i}\left[U_{5}-U_{3} \cos 4 \theta i\right] \\
& A_{16}=\sum_{i=1}^{I} h_{i}\left[U_{2} / 2 \sin 2 \theta i+U_{3} \sin 4 \theta i\right] \\
& A_{26}=\sum_{i=1}^{I} h_{i}\left[U_{2} / 2 \sin 2 \theta_{i}-U_{3} \sin 4 \theta i\right]
\end{aligned}
$$

ここで, $U_{i}$ は剛性に咸するボ变量である6).

面内剛性 $A_{i j}$ は, 層厚に関しては一次閔数であるが, 瀻維角に対しては $\cos 2 \theta, \cos 4 \theta, \sin 2 \theta, \sin 4 \theta$ からな る複雑な関数である. 積層材の層厚に加え㵶維角を最適 化するとき，直接に繊維角を設計変数とすると，しばし ば，局所的な最適点で計算がストップする，そのため， 㵶維角に対しては, 適当な中間変数を導入して, 剛性と 緘維角との関係の非線形性の程度を下げ，局所的な最適 点をできるたけ生じないような解法を必要とする．たと えば，積層パラメータ7を中間的な設計変数として用い ることができれば剖性と線形関係になる。一般的なアン ハシランスト積層材に対する程層ハランークと秙層構成の 関係はまだ未解決の問題であり，また，通常の破損規準 は繊維角と值接に関係するため, 強度最適化問題で積層 パラメータを設計変数に朋いることはできない。

単一荷重の場合は, 前報2)で，せん断荷重がゼ口とな る主荷重方向のパランスト材について最適化する手法を 報告した. ハシランスト材では風性特性において， $A_{16}=$ $A_{26}=0$ となり，他の㴊性成分は $\cos 2 \theta$ と $\cos 4 \theta$ のみ の関数となるため, $\cos 2 \theta$ を設部变数にすれば $\cos 2 \theta$ の二次関数で表示できることになる．この手法は単一荷

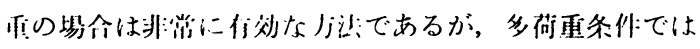

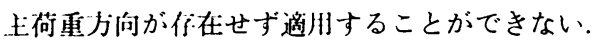

本報では，織維角の最適化に阅し，小闍似に $\cos 2 \theta$ 


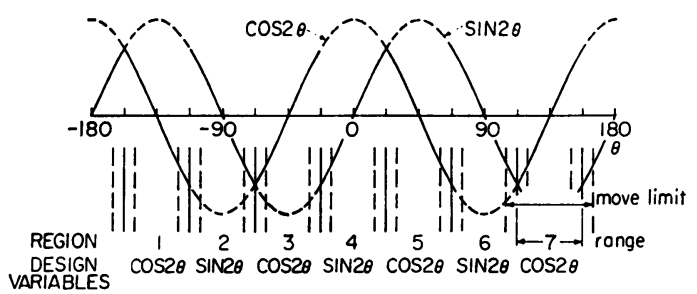

Fig. 2 Region division and design variables.

か $\sin 2 \theta$ を設計変数に用いる手法を提案する. $\cos 2 \theta$ を設計変数とするとき， $\theta$ の值により $\sin 2 \theta$ の符号が変 化する. そこで, Fig.2 に示すように，まず, 繊維角の) 值により $\cos 2 \theta$ か $\sin 2 \theta$ の符号が変化しない各領域に 分割する. たとえば，緘維角が $45^{\circ}$ であるとき，その層 は領域 5 に属する. 領域 5 では $\cos 2 \theta$ は $\theta$ の単調減少 闺数であり, $\sin 2 \theta$ は正の関数である. この領域では, $x=\cos 2 \theta$ を設計変数に用いることにする，同様に，邻 域 4 では $x=\sin 2 \theta$ を設計変数とする．そのとき，

解域 4:

$$
\left.\begin{array}{ll}
x_{i}=\sin 2 \theta i, & \cos 2 \theta i=\sqrt{1-x i^{2}} \\
\cos 4 \theta_{i}=1-2 x_{i}{ }^{2}, & \sin 4 \theta i=2 x_{i} \sqrt{1-x i^{2}} \\
5: & \\
x_{i}=\cos 2 \theta_{i}, & \sin 2 \theta i=\sqrt{1-x i^{2}} \\
\cos 4 \theta i=2 x_{i}{ }^{2}-1, & \sin 4 \theta_{i}=2 x_{i} \sqrt{1-x i^{2}}
\end{array}\right\}
$$$$
\text { 呫域 } 5 \text { : }
$$

最適化過程で織維角は異なる 領域に 移動することが考 えられるが，絨維角が過度に隣接領域に移動すると数值 的张動を起こしやすいので，収束特性の安定化を図るた め move limit を設远する. Table 1 に変換した設計変 数と move limit を䒕な.ここでは, move limit の籁 明は $\Delta \theta=7.5^{\circ}$ とする。

Fig. 3 に取適化のソローチャートをふ小寸。まず, 蟣維

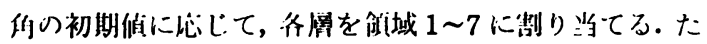

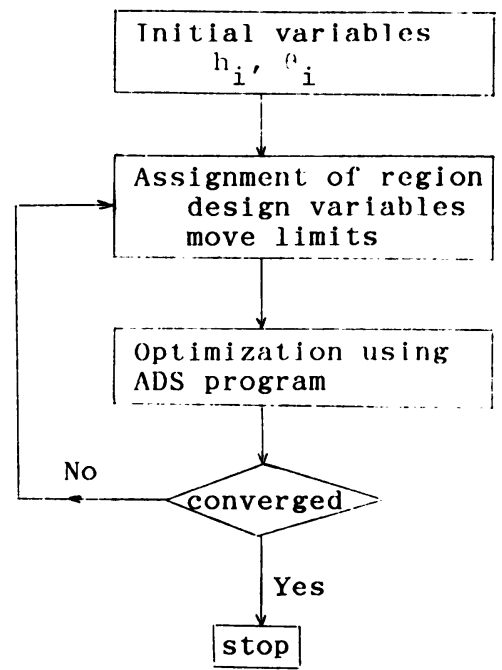

Fig.3 Flow chart for the optimization.

とえば，初期繊維角が $\theta_{1} / \theta_{2} / \theta_{3} / \theta_{4}=0 / 90 / 45 /-45$ であ 万とき， $\theta_{1} \sim \theta_{4}$ は，それぞれ，領域 4，6，5，3 に属与 る. そのとき, Table 1 に示寸変換した設計変数，お上 び, move limitを用いて最道化算を行う。ここでは, $\operatorname{ADS}$ プログラム $^{8)}$ の許容方向法（一次元探索は黄金分割 沙）を用いる. 聂適化計算の後では, 絨維角が元の頜域 と隣接する領域に移動することが考えられるので, 最適 化後の織維角に応じて新たに設計変数と move limit を 没定する。この反復部算を収束するまで緑り这す。

\section{4. 数 值 計 算 例}

数值計算に用いた炭素織維/エボキシ忯の材料定数を Table 2 に示す，以下の数值例では，まず，縤-·荷重の 埸合について前報で用いた沙とひ比較を行い，次に，

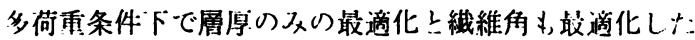

Table 1 Transformed design variables and move limits.

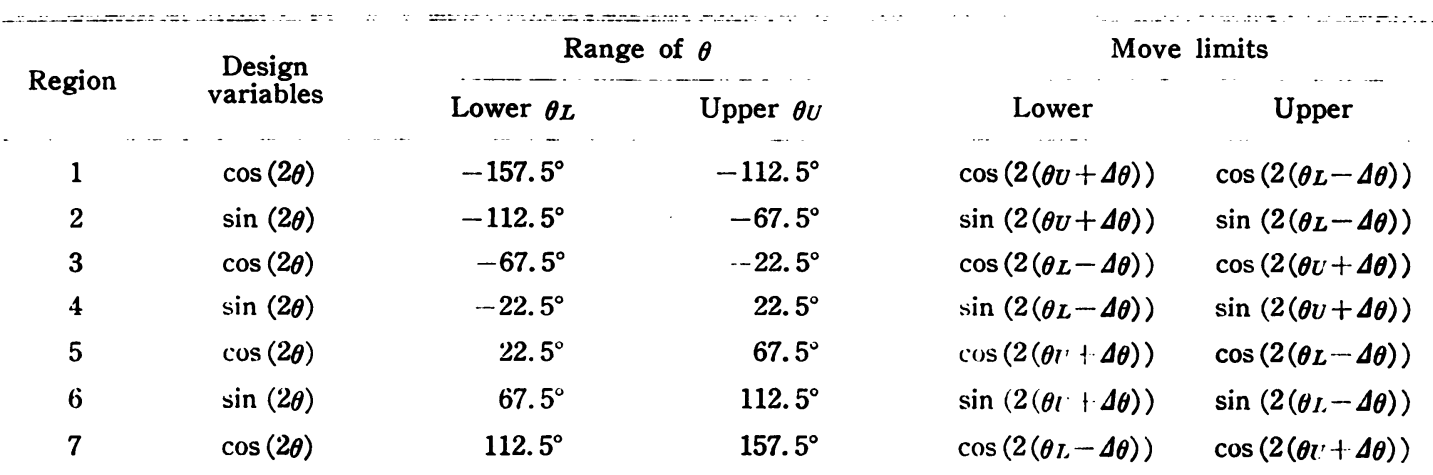


Table 2 Material constants of graphite/epoxy composites.

$$
\begin{aligned}
& E_{L}=142 \mathrm{GPa}, \quad E_{T}=10.8 \mathrm{GPa}, \quad G_{L T}=5.49 \mathrm{GPa}, \quad \nu_{L}=0.3 \\
& F_{L}=1.568, \quad F_{L^{\prime}}=1.341, \quad F_{T}=0.057, \quad F_{T^{\prime}}=0.212, \quad F_{L T}=0.08(\mathrm{GPa})
\end{aligned}
$$

\section{塨合の此較を示す。}

\section{1 単一荷重条件の場合}

Table 3 に, 8 種類の単一衡重条件の場命について, 最小重量および最適な積層構成を示す，強度基準として は Tsai-Wu 則 $\left(F_{12} *=-1 / 2\right)$ を使用する. 設計变数 は $\theta_{1} / \theta_{2} / \theta_{3} / \theta_{4}$ 䅡層材の瀻維角および層厚の汁 8 偑, 制 約条作数は各織維角に対伈する4佩である，層厚の下限 值として 0.01 を用いる. 繊維角に対しては Table 1 に 示す変換した設計变数を用い, Fig. 3 のフローチャート に従い収束するまで反復汁算を行う，各荷重条件につい て, Table 3 脚注に六寸 4 種類の初期値を用いる. また, Table 3 に, 収束するまでの反復问数, および, 最適解 におけるアクティブ（クリティカル）な制約条件を命せ 亦与.

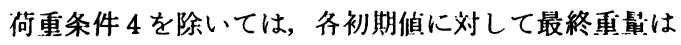
ほとんど闰じ車量を方える. 何重条件 1 と 7 の場合は, 前報2)で六したと间様に，间时破損稓層構成が最適な静

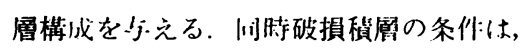

$$
\begin{aligned}
& \sum_{i=1}^{4} h_{i} \cos 2 \theta_{i}=0, \quad \sum_{i=1}^{4} h_{i} \sin 2 \theta_{i}=0, \\
& h_{i} \geqq 0
\end{aligned}
$$

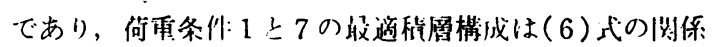
を满たす。

荷重条件 2 と 8 では, 初期值により, 最適䅡風構成は

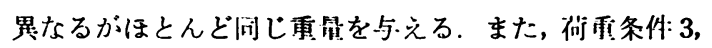

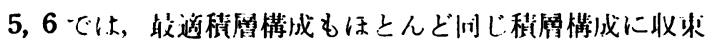

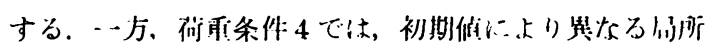
设適点に注与。。

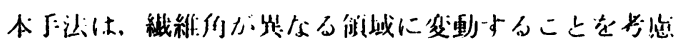
して, 反復汒算により瀻維角の最適化を行って抢り, 収

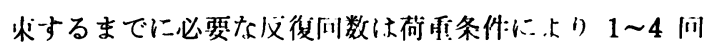
程度である。

次に，前報2)で提条したす法との比較を行う，Fig. 4

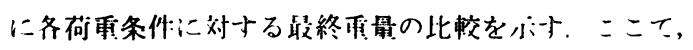
次ひ 4 通りのノ江を㖄いる.

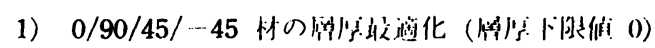

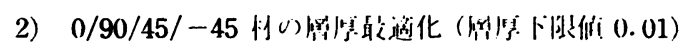

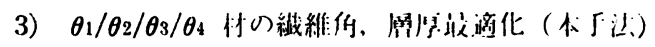

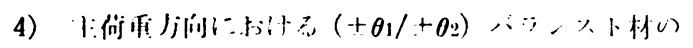

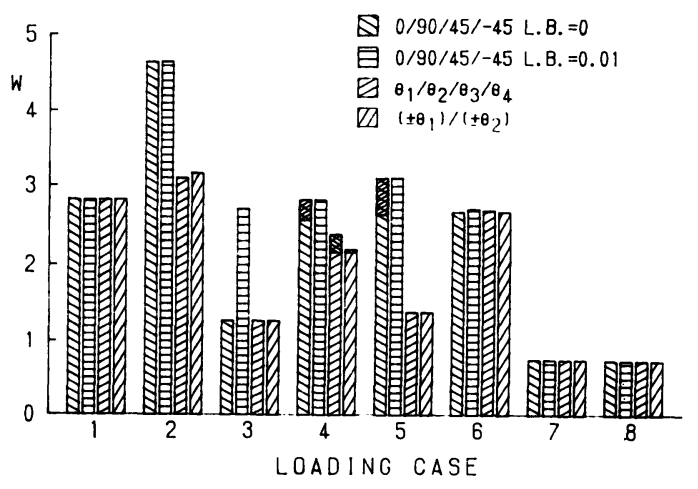

Fig. 4 Comparison of final weights for the single loading case.

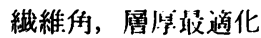

Fig.4 に损いて，因部は初期倠による最小重量のばら つき（収束の不安定悱）を示寸，荷重条件 2 と 5 で，煟 厚に加え㵶維角を最適化することの氒要性が見られる.

手法 3 と 4 はほとんど问じ重盛を与えるが，手法 3 では 反復部算を用いているのに対し, 法 4 では一回の最適 化部算で斎む。 また，手泣 3 の最適稅層棈成が若干の初 期估作存性を示すのに対し，一治４は初期优依存性のな い安定した収束特性を示す。このうに，巣一荷車の場 介の絨維角最適化の方泣としては, 主荷重方向に幽漂変 換してハシランスト材について最滴化する力法がより優れ。 ている.

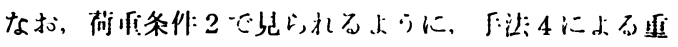

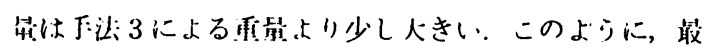

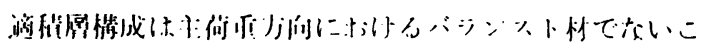

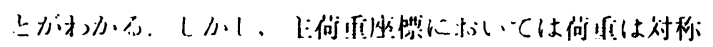

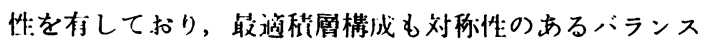
ト材のなか・あるもの之考えられるが，この数优例は

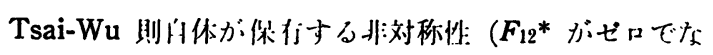
い性啠）によるもの上洪沈らる。

\section{2 多荷重条件の場合}

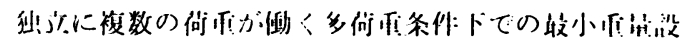

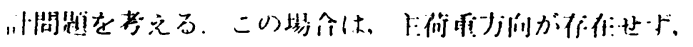

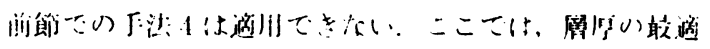

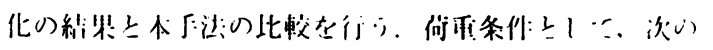

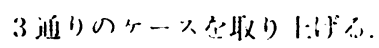


Table 3 Optimal laminate configurations of $\left(\theta_{1}\right)_{h_{1}} /\left(\theta_{2}\right) h_{2} /\left(\theta_{3}\right)_{h_{3}} /\left(\theta_{4}\right)_{h_{4}}$ laminates (single loading).

Laminate configurations

\begin{tabular}{|c|c|c|c|c|c|c|c|c|c|c|c|c|}
\hline$\left(N_{x}, N_{y}, N_{x y}\right)$ & $\ldots$ & $\begin{array}{c}\theta_{1} \\
(\mathrm{deg} .)\end{array}$ & $\begin{array}{c}\theta 2 \\
\text { (deg.) }\end{array}$ & $\begin{array}{c}\theta 3 \\
(\mathrm{deg} .)\end{array}$ & $\begin{array}{c}\theta 4 \\
(\text { deg. })\end{array}$ & $h_{1}$ & $h_{2}$ & $h_{3}$ & $h_{4}$ & $W=\sum h_{i}$ & I.N. & $\begin{array}{c}\text { Critical } \\
\text { constraints }\end{array}$ \\
\hline Case 1 & 1 & 13.3 & -42.6 & 43.5 & 103.3 & 0.65 & 0.69 & 0.73 & 0.75 & 2.822 & 1 & $1,2,3,4$ \\
\hline \multirow[t]{3}{*}{$(1,1,0)$} & 2 & -2.9 & -51.2 & 50.6 & 92.2 & 0.89 & 0.59 & 0.73 & 0.62 & 2.822 & 1 & $1,2,3,4$ \\
\hline & 3 & 2.4 & -39.4 & 38.9 & 87.2 & 0.62 & 0.73 & 0.59 & 0.89 & 2.822 & 1 & $1,2,3,4$ \\
\hline & 4 & -30.1 & 27.4 & 60.0 & 92.4 & 0.92 & 0.85 & 0.21 & 0.85 & 2.822 & 1 & $1,2,3,4$ \\
\hline Case 2 & 1 & 28.2 & -37.5 & 28.2 & 86.3 & 0.09 & 0.74 & 2.26 & 0.01 & 3.096 & 2 & 2 \\
\hline \multirow[t]{3}{*}{$(1,0,1)$} & 2 & 27.7 & -37.2 & 28.1 & 86.0 & 0.01 & 0.74 & 2.34 & 0.01 & 3.096 & 3 & 2,4 \\
\hline & 3 & 27.8 & -37.5 & 28.4 & 86.0 & 0.64 & 0.74 & 1.71 & 0.01 & 3. 097 & 2 & 2,4 \\
\hline & 4 & -22.3 & 35.5 & 35.5 & 100.1 & 0.01 & 1.94 & 0.40 & 0.75 & 3.096 & 2 & 1,4 \\
\hline Case 3 & 1 & 45.0 & 43.7 & 45.1 & 45.1 & 0.01 & 0.01 & 1.25 & 0.01 & 1.276 & 4 & $1,2,3,4$ \\
\hline \multirow[t]{3}{*}{$(1,1,1)$} & 2 & 43.4 & -134.7 & 45.1 & 45.3 & 0.01 & 0.01 & 1.25 & 0.01 & 1.276 & 3 & $1,2,3,4$ \\
\hline & 3 & 44.8 & -133.4 & 44.9 & 46.6 & 0.01 & 0.01 & 1.25 & 0.01 & 1.276 & 4 & $1,2,3,4$ \\
\hline & 4 & 43.5 & 43.9 & 48.9 & 48.9 & 0.01 & 1.02 & 0.24 & 0.01 & 1.279 & 3 & $1,2,3,4$ \\
\hline Case 4 & 1 & 16.3 & 16.3 & 75.0 & 77.2 & 0.97 & 0.16 & 0.01 & 1.03 & 2.162 & 4 & $1,2,4$ \\
\hline \multirow[t]{3}{*}{$(1,1,0.5)$} & 2 & 30.5 & -81.2 & 30.5 & 98.8 & 0.62 & 0.25 & 1.06 & 0.46 & 2.389 & 2 & $1,2,3,4$ \\
\hline & 3 & 10.7 & 10.7 & 72.3 & 72.3 & 0.85 & 0.15 & 0.34 & 0.83 & 2. 172 & 3 & $1,2,3,4$ \\
\hline & 4 & -3.9 & 61.8 & 61.8 & 61.8 & 0.76 & 0.60 & 0.65 & 0.31 & 2.316 & 2 & $1,2,3,4$ \\
\hline Case 5 & 1 & 21.9 & 21.3 & 23.2 & 23.7 & 0.76 & 0.01 & 0.61 & 0.01 & 1.392 & 2 & 2,4 \\
\hline \multirow[t]{3}{*}{$(1,0,0.5)$} & 2 & 22.7 & 20.6 & 22.3 & 24.1 & 0.81 & 0.01 & 0.56 & 0.01 & 1.392 & 2 & 2,4 \\
\hline & 3 & 21.7 & 20.8 & 23.4 & 24.4 & 0.74 & 0.01 & 0.63 & 0.01 & 1.393 & 2 & 2,4 \\
\hline & 4 & 22.2 & 22.5 & 22.7 & 22.7 & 0.01 & 1.36 & 0.01 & 0.01 & 1.391 & 2 & $1,2,3,4$ \\
\hline Case 6 & 1 & -0.1 & -34.9 & 35.0 & 90.1 & 1.69 & 0.01 & 0.01 & 0.98 & 2.690 & 2 & 4 \\
\hline \multirow[t]{3}{*}{$(1,-1,0)$} & 2 & 0.8 & -45.2 & 44.6 & 88.6 & 1.72 & 0.01 & 0.01 & 0.95 & 2.693 & 1 & 4 \\
\hline & 3 & -0.3 & -36.0 & 37.6 & 90.5 & 1.70 & 0.01 & 0.01 & 0.97 & 2.691 & 1 & 4 \\
\hline & 4 & 1.2 & 2.5 & 70.3 & 86.5 & 0.39 & 1.31 & 0.01 & 0.97 & 2.681 & 3 & 4 \\
\hline Case 7 & 1 & 0.0 & -45.0 & 45.0 & 90.0 & 0.19 & 0.19 & 0.19 & 0.19 & 0.757 & 1 . & $1,2,3,4$ \\
\hline \multirow[t]{3}{*}{$(-1,-1,0)$} & 2 & -2.1 & -47.4 & 48.0 & 91.6 & 0.21 & 0.17 & 0.20 & 0.17 & 0.757 & 1 & $1,2,3,4$ \\
\hline & 3 & 1.6 & -41.9 & 42.6 & 87.9 & 0.17 & 0.20 & 0.17 & 0.21 & 0.757 & 1 & $1,2,3,4$ \\
\hline & 4 & -30.7 & 28.4 & 59.9 & 91.6 & 0.25 & 0.24 & 0.04 & 0.24 & 0.757 & 1 & $1,2,3,4$ \\
\hline Case 8 & 1 & 1.1 & -45.0 & 39.3 & 88.9 & 0.14 & 0.44 & 0.01 & 0.15 & 0.746 & 1 & 2 \\
\hline \multirow[t]{3}{*}{$(-1,-1,0.5)$} & 2 & -3.2 & -40.6 & 40.3 & 92.3 & 0.13 & 0.40 & 0.01 & 0.20 & 0.745 & 1 & 2 \\
\hline & 3 & 0.4 & -46.0 & 46.0 & 89.3 & 0.14 & 0.45 & 0.03 & 0.12 & 0.746 & 1 & 2 \\
\hline & 4 & -31.9 & 42.1 & 65.8 & 89.6 & 0.51 & 0.01 & 0.01 & 0.21 & 0.743 & 2 & 1,4 \\
\hline \multicolumn{13}{|c|}{$\begin{array}{l}1-(0,-45,45,90,1,1,1,1), 2-(0,-45,45,90,2,1,2,1), 3-(0,-45,45,90,1,2,1,2) \\
4-(-30,30,60,90,1,1,1,1), \quad \theta i \text { (deg.). }\end{array}$} \\
\hline
\end{tabular}


(a) $\quad\left(N_{x}, N_{y}, N_{x y}\right)=(1,1,1),(2,1,0),(0,0,-1.5)$

(b) $\left(N_{x}, N_{y}, N_{x y}\right)=(2,0.5,1),(-1.5,0.5,-1)$, $(1,0.5,1.5)$

(c) $\quad\left(N_{x}, N_{y}, N_{x y}\right)=(1,0,0),(0,-1,0),(0,0,1)$
また，次の 3 通りの力法を特いたときの取適解を此軟す る.

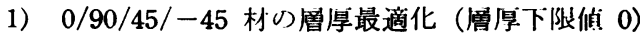

2) $0 / 90 / 45 /-45$ 材の層厚最適化（層厚下限値 0.01）

Table 4 Optimal laminate configurations of $0 / 90 / 45 /-45$ laminates (multiple loading).

\begin{tabular}{|c|c|c|c|c|c|c|c|}
\hline \multirow{2}{*}{\multicolumn{2}{|c|}{$\left(N_{x}, N_{y}, N_{x y}\right)$}} & \multicolumn{4}{|c|}{ Thickness components } & \multirow{2}{*}{$W=\sum h_{i}$} & \multirow{2}{*}{$\begin{array}{c}\text { Critical } \\
\text { constraints } \\
(k i)\end{array}$} \\
\hline & & $h_{0}$ & $h_{90}$ & $h_{45}$ & $h_{-45}$ & & \\
\hline Case 1 & A 1 & 0.65 & 0.00 & 2.42 & 2.00 & 5.066 & $14,23,33$ \\
\hline$(1,1,1)$ & A2 & 0.65 & 0.00 & 2.42 & 2.00 & 5.062 & $14,23,33$ \\
\hline$(2,1,0)$ & A3 & 0.65 & 0.00 & 2.42 & 2.00 & 5.063 & $14,23,33$ \\
\hline \multirow{7}{*}{$(0,0,-1.5)$} & A4 & 0.65 & 0.00 & 2.42 & 2.00 & 5.062 & $14,23,33$ \\
\hline & A5 & 0.65 & 0.00 & 2.42 & 2.00 & 5.062 & $14,23,33$ \\
\hline & B 1 & 1.11 & 0.01 & 2.37 & 1.96 & 5.458 & $14,22,33$ \\
\hline & B2 & 1.11 & 0.01 & 2.37 & 1.96 & 5.458 & $14,22,33$ \\
\hline & B3 & 1.11 & 0.01 & 2.37 & 1.96 & 5.458 & $14,22,33$ \\
\hline & B4 & 1.11 & 0.01 & 2.37 & 1.96 & 5.458 & $14,22,33$ \\
\hline & B5 & 1.11 & 0.01 & 2.37 & 1.96 & 5.458 & $14,22,33$ \\
\hline Case 2 & A1 & 1.36 & 1.27 & 3.05 & 0.96 & 6.629 & $12,21,34$ \\
\hline$(2,0.5,1)$ & A2 & 1.36 & 1.26 & 3.05 & 0.96 & 6.629 & $12,21,34$ \\
\hline$(-1.5,0.5,-1)$ & A3 & 1.33 & 1.33 & 3.13 & 0.85 & 6.628 & $12,21,34$ \\
\hline \multirow[t]{7}{*}{$(1,0.5,1.5)$} & A4 & 1.38 & 1.23 & 3.00 & 1.03 & 6.633 & $12,21,34$ \\
\hline & A5 & 1.36 & 1.26 & 3.05 & 0.96 & 6.630 & $12,21,34$ \\
\hline & B 1 & 1.36 & 1.27 & 3.05 & 0.96 & 6.629 & $12,21,34$ \\
\hline & B2 & 1.36 & 1.26 & 3.05 & 0.96 & 6.629 & $12,21,34$ \\
\hline & B3 & 1.33 & 1.33 & 3.13 & 0.85 & 6.628 & $12,21,34$ \\
\hline & B4 & 1.38 & 1.27 & 3.00 & 1.03 & 6.633 & $12,21,34$ \\
\hline & B5 & 1.36 & 1.26 & 3.05 & 0.96 & 6.630 & $12,21,34$ \\
\hline Case 3 & $\mathrm{~A} 1$ & 0.65 & 0.00 & 1.57 & 1.04 & 3.264 & 24,34 \\
\hline$(1,0,0)$ & A2 & 0.65 & 0.00 & 1.56 & 1.05 & 3.262 & 24,34 \\
\hline$(0,-1,0)$. & A3 & 0.96 & 0.15 & 1.65 & 0.90 & 3.654 & $12,22,34$ \\
\hline \multirow[t]{7}{*}{$(0,0,1)$} & A4 & 0.65 & 0.00 & 1.56 & 1.05 & 3. 262 & 24,34 \\
\hline & A5 & 0.96 & 0.15 & 1.63 & 0.92 & 3.653 & $12,22,34$ \\
\hline & $\mathrm{B} 1$ & 0.96 & 0.15 & 1.61 & 0.93 & 3.653 & $12,22,34$ \\
\hline & B2 & 0.96 & 0.15 & 1.63 & 0.92 & 3.653 & $12,22,34$ \\
\hline & B3 & 0.96 & 0.15 & 1.63 & 0.92 & 3.653 & $12,22,34$ \\
\hline & B 4 & 0.96 & 0.15 & 1.60 & 0.95 & 3.656 & $12,22,34$ \\
\hline & B5 & 0.96 & 0.15 & 1.63 & 0.92 & 3.653 & $12,22,34$ \\
\hline
\end{tabular}

* Lower bound : 0 (case A), 0.01 (case B).

** Initial points : $1-(2,2,2,2), 2(2,1,2,1), 3(1,2,3,4), 4-(4,3,2,1), 5 \cdots(1,3,2,4)$.

*** Critical constraints $k i: k$-loading number, $i$-layer number. 


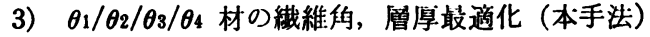
このとき，設計変数の数は，それぞれ，4，4，8 個であ わ，制䄪条件数は，12 佔である。

(1) $0 / 90 / 45 /-45$ 材

Table 4 に 0/90/45/-45 材の成厚聂適化の絬果を示 す。问衣脚泿に示す 5 通りの初期值および 2 通りの層厚 の下限倠（A：下限估 0， B ：下限值 0.01）を朋いる. また，间韯に分すように，最適絬果でアクティブ(クリ ティカル）な制約条件を $k i(k:$ 荷重番号， $i$ : 層番号) で烺す，荷禹条作 3A を除いては, 最終の重量および最 適㿠㕌構成とも，初期值にかかわらず同一の結果に収束 する. 荷重条作 $3 \mathrm{~A}$ では, 初期值 A1，A2，A4 は大局 的な最道倠に收次し, 初期佰 $\mathrm{A} 3, \mathrm{~A} 5$ は局所的な最適値 に到達する，層曆の下限值が重量に及ぼす効果は，荷重 ケース 1 と 3 で裴れるか，前報2 で求めた単一荷重の坋 令に比べその効果は小さい，これは，相反する荷重条件 が多くあるほど，最適な䅡層構成が方向性のより少ない 程熷棈成に近付いていくことによる。

(2) $\theta_{1} / \theta_{2} / \theta_{3} / \theta_{4}$ 材

Table 5 に変换した設部变数に基一うく $\theta_{1} / \theta_{2} / \theta_{3} / \theta_{4}$ 材 についての最適絬果を示す，最適計算はFig. 3 に示す民
復計算に基へういており，最適解を得るのに必要な仅復回 数も同表に示す。また，用いた初期値は同表脚注に示す 4 涌りであり，層厚の下限值は 0.01 である。すすへての 荷重条件について，異なる初期值から出発しても最終の 重量はほぼ同しととなる，最適な積層構成については，荷 重条件 2 では同一の積層構成に収束し，荷重条件 1 では 初期值 4 とよる結果だけが少し異なった積層構成を示 寸。また, 何重条件 3 では, 初期值 1 と 3 , 初期值 2 と 4 が，二つの異なる積層構成に達する.

(3) 最小重量の比較

Fig. 5 に 3 通りの方法を朔いた垬合の最小重量の比較 を示す．图は初期值によるばらつきを示す．層厚に加え 㵶維牦を最適化する効果は荷重条件 2 に見られるが，単 一荷重の場合ほどは顕著でない。

\section{5. 結 論}

本满文では，面队荷重を受ける皘層材の強度最適化に おいて，䄉維角に関して变换した設計変数を用いるテ法 を捉案した，すなわち，強度制約条件と㵶維角の間の非 線形性を減少させるため, 瀻維角の值により备領域に分 制し，各领域で $\cos 2 \theta$ か $\sin 2 \theta$ を設計变数として用い

Table 5 Optimal laminate configurations of $\left(\theta_{1}\right)_{h_{1}} /\left(\theta_{2}\right)_{h_{2}} /\left(\theta_{3}\right)_{h_{3}} /\left(\theta_{4}\right) h_{4}$ laminates (multiple loading).

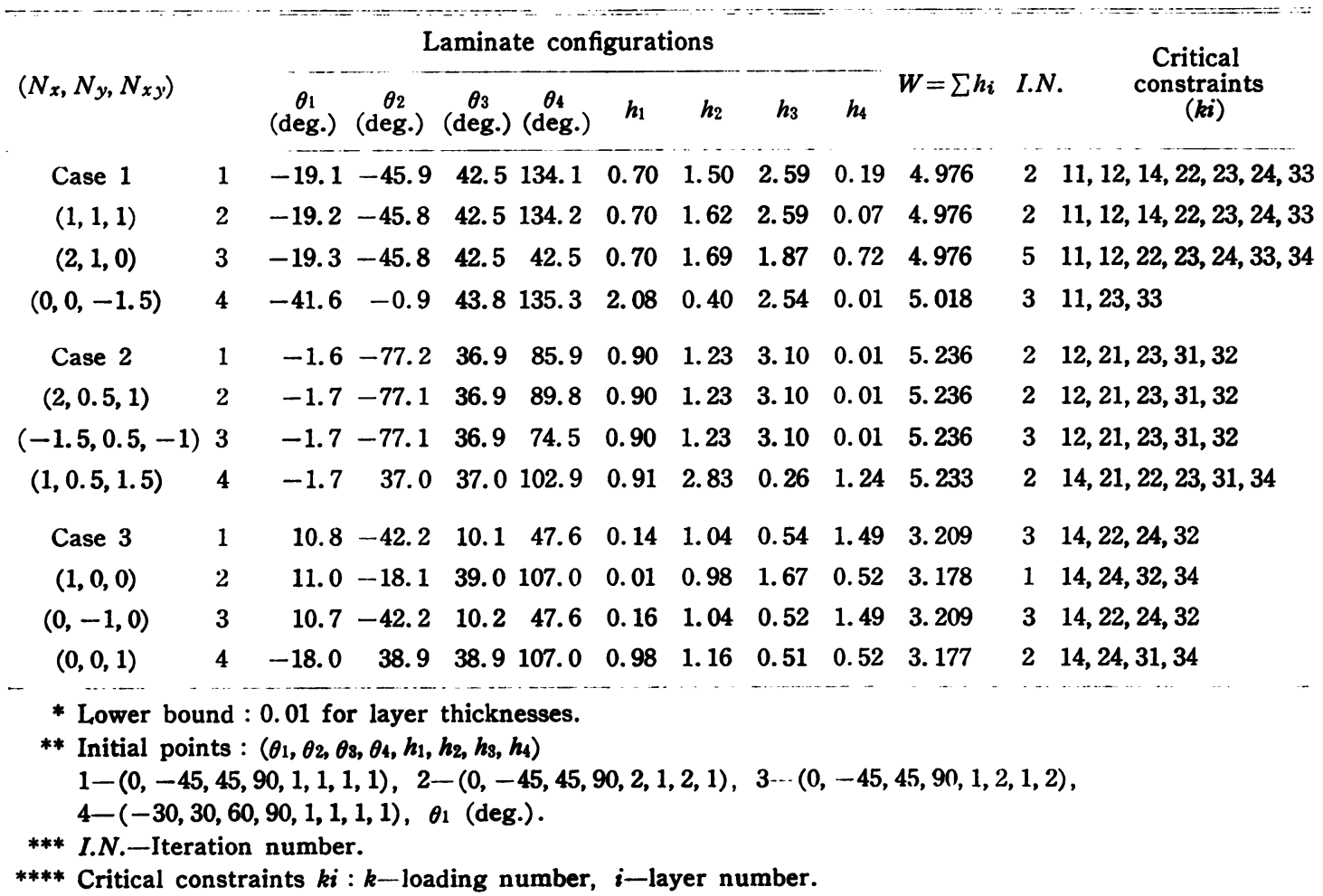




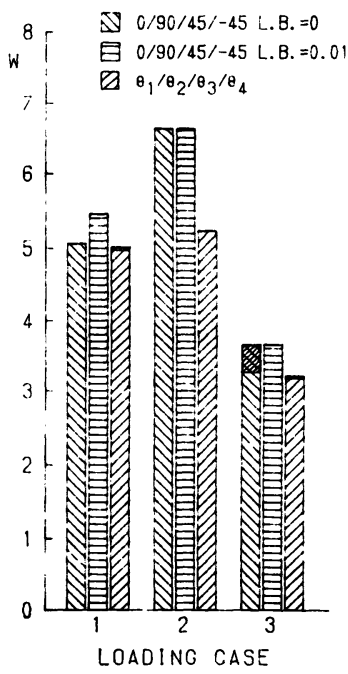

Fig. 5 Comparison of final weights for the multiple loading case.

る.この和法により，単一荷重条件の場合と多荷量条件 の場合の強度最適化の数㑤例を心゙.た。

単一荷重条件の場合は，前報で提条した荷重方仙に おけるハラランスト材について最適化する乎法が, 本非法 より優れている，一开，多荷重条件下では，本手法によ り繊維角と層厚の最適化を行い, 庩厚のみの最適化の場
公との比較を行った。本丰法は，若壮の初期值依你性を 示すが, 数问の反復回数で最適な積層構成を求めること ボでき，䄉維㑇の最適化に対しかなり有効に機能すか.

本砳究に際し ADS プログラムを使わせて頂いた VMA エンジニアリング Vanderplaats 博士に感謝致し ます.

\section{参考文献}

1）福永久雄：日本複合材料学会誌，16 (1990)，7582, 115-122.

2) 福永久雄, G.N. Vanderplaats : 日本複合材料学 会誌, 16 (1990), 102-109.

3) W.J. Park :J. Compos. Mater., 21 (1987), 532-535.

4) R.I. Watkins \& A.J. Morris : Comp. Methods Appl. Mech. Eng., 60 (1987), 233-251.

5) L.A. Schmit \& B. Farsi : Int. J. Numer. Methods Eng., 7 (1973), 519-536.

6) S.W. Tsai \& H.T. Hahn : Introduction to Composite Materials, Technomic Publ., Westport (1980).

7) 福永久雄：日本複合材料学会憝，12（1986），6572.

8) G.N. Vanderplaats \& H. Sugimoto : Int. J. Comput. Struct., 24 (1986), 13-21. 